\title{
The theological coherence between the Belhar confession and some antecedent church witnesses in the period 1948- 1982
}

\author{
P Naude \\ (University of Port Elizabeth)
}

\section{ABSTRACT \\ The theological coherence between the Belhar confession and some antecedent church witnesses in the period 1948-1982}

This article explores the historical and theological relation between the Confession of Belhar (1982) and some significant antecedent church witnesses from 1948 onward. After identifying these witnesses, a coherence is sought in the confessional interpretation of the SA situation, and core theological themes linked to ecclesiology, Christology and anthropology that served as basis for the vision of an alternative society. Although Belhar is no "summary" of these witnesses, an interpretation of the confession is enhanced by reading it against the ecumenical history of the time.

A confession of faith cannot be carefully planned like a systematic theology or a catechism. The very nature of a confession as a moment of truth when the church "is hit on the mouth to proclaim credo" (Barth), renders it highly contextual and time-bound ${ }^{1}$, though obviously not without wider and further significance beyond its own time. This kairoscharacter does nevertheless not detract from the fact that a confession does not "fall from the sky" without significant antecedent developments.

The people involved in formulating and accepting a confession bring with them their own histories and shaped convictions. The biblical and theological roots of a Christian confession lie far behind the confession itself in the canon, the tradition (including earlier confessions), and continued reinterpretations thereof. In fact, the confession is a confession not because it wants to declare an unknown secret, or spring a surprise on the church, but exactly because it aims at a renewed interpre-

1 Karl Barth's famous definition and subesequent dicussion of a confession in the KD 1/2:693-740 includes this inherent contextuality in a number of ways: A confession is a proclamation of the church in a specific situation, which requires the interpretation of a specific location (geographical), at a specific moment (reading the signs of the times), about a specific issue (focused content of the confession), thus placing the confession in the midst of political, cultural and economic realities of society (see Barth 1948:700). For broader views on Barth and confessions, see Dirkie Smit's overview (2000:76-86) and Georg Plasger (2000). 
tation of what is known, but presently lost or concealed ${ }^{2}$. The social, economic and political developments that precede and "inform" a confession are mostly not neutral, and - due to their theological interpretation by the confession - are themselves at stake in the act of confession.

This is also true for the confession of Belhar, adopted in its draft form by the Dutch Reformed Mission Church in September/October 1982 and finally as fourth confessional basis in 1986. I believe that part of Belhar's power lies in constantly keeping the context and preceding tradition from which it grew in mind. Like a responsible hermeneutics of the Bible requires some understanding of the world "behind the text" as well as the possible layers in the text and its formation, it would be wise to investigate some of the important texts historically "underlying" the Belhar confession.

The assumption is obviously not that Belhar is the summary of other documents, like a kind of "final conclusion" where everything declared earlier is retrieved in some balanced overview. A confession is not a report. Neither should one look for mere verbal agreements or corresponding phrases that might be important like in ancient textcomparisons and text-critical work on the Bible. My proposal is that we attempt to find some theological coherence amongst a selection of documents critical of apartheid preceding Belhar, and determine the resonance between that coherence and Belhar. This is not an exercise in interesting church history - it is a legitimate requirement for the interpretation of the Belhar text. Such interpretation ${ }^{3}$ is itself not attempted here, though a few pointers for work still to be done, flow from the discussion below.

2 John de Gruchy (1983:83) refers to J C Wand: The four great heresies (1955) who indicates that the first trait of a heresy is that it brings something novel into the church. My dogmatics professor at Stellenbosch, Willie Jonker, used to remark: "If one day you say something completely new in the church, you are probably erring".

3 A theological interpretation of Belhar is still in its infancy if compared with the elaborate work done on e.g. the Barmen declaration in Germany (see volumes on the different articles of Barmen by the Evangelische Kirche der Union between 1981 and 1994). Although Belhar is now more than twenty years old, only a handful of articles have been written since $A$ moment of truth apperared in 1984 (see Cloete and Smit). See my booklet with Johan Botha, Op pad met Belhar (1998) as well as Naude 1997 (ecumenical perspective on Belhar) and 2003 (application of textreception theory to Belhar). Dirkie Smit has done some work to introduce Belhar to a wider audience in Germany (Smit 1998) and The Netherlands (Smit 2000). To promote international reflection, I presented an Oberseminar on Belhar with Bill Schweiker (Chicago) and Michael Welker (Heidelberg) during the winter semester of 2002-2003 at the University of Heidelberg. 
Which documents will be analysed? $?^{4}$ My choice for this paper is a selection of church or ecumenical statements critical of apartheid in the period from 1948 to the draft version of Belhar in 1982. This is in itself not an original idea, as Apartheid is a heresy (De Gruchy and VillaVicencio 1983), Bonhoeffer and South Africa (De Gruchy 1984) and Between Christ and Caesar (Villa-Vicencio 1986) ${ }^{5}$ already listed and discussed historically important documents directed against apartheid. Apart from adding a small, but significant, earlier document to the lists available, I hope to contribute in constructing a theological coherence from these documents, and relate them to the Belhar text. This has not been done before. It will complement the earlier literature on the theological resistance against apartheid, and will hopefully heighten interest in the continued theological appropriation of Belhar itself.

These documents, remarkably representing Catholic, Lutheran, Ecumenical and Reformed views, are in chronological order:

* Dutch Reformed Mission Church: Circuit of Wynberg decision on apartheid $^{6}(1948)$;

4 There are historically three periods to choose from: I) The early church, when faith consensus was reached in the credos of Nicea, Athanasius and the Apostolicum. ii) The Reformation period, and beyond, with numerous categetical and confessional writings, including the Three Formulaes of Unity (Belgic Confession, Heidelberg Cathecism, Canons of Dordt) that formed the confessional base of the DRMC until 1986. iii) The twentieth century, with a focus on the Barmen declaration in Germany and growing resistance against apartheid in South Africa. My choice for the last period does not exclude my interest in the resonance between Belhar and the earlier creeds and confessions - especially in light of the WCC process to re-appropriate Nicea (see Confessing the one faith , 1991), and criticism that Belhar is not really a confession in the Reformed sense of the word (note report by R Britz in the Northern Cape Synod of the DRC, 1999).

5 Readers are referred to this book for most of the texts. I will quote from the texts using their internal numbering, where available.

6 Since this decision is relatively unknown and short enough, it is quoted here in full (my translation). It is a remarkable statement of September 1948, the year in which the National Party came to power: The circuit of Wynberg of the DRMC in SA accepts the following motion with regard to the policy of apartheid in our country: 1. The circuit declares that they find no grounds in the Holy Scripture for colour-based apartheid 2. This body objects against the proposed apartheid laws and does an earnest appeal to the government not to apply any "forced" apartheid laws. 3. The circuit also requests in a friendly manner that the government will accept as principle to always consult representative coloured leaders regarding proposed legislation affecting coloureds, and that the co-operation of the coloureds be a condition for policy implementation. 4. The circuit ensures that the Christians from this circuit's area will pray (voorbidding: intercession) that the government will be led to deal with all coloured groups in our country in a Christian manner. 
* SA Catholic Bishop's Conference ${ }^{7}$ Statement on apartheid (1957);

* Cottesloe Consultation Statement (1961);

* SACC's Message to the People of South Africa (authorised summary, 1968);

* Lutheran World Federation's statement Southern Africa: Confessional Integrity (Dar-es-Salaam 1977);

* Alliance of Black Reformed Christians in Southern Africa (ABRECSA): Charter and Declaration (Oct 1981);

* Open Letter by 123 Dutch Reformed Church pastors and theologians $^{8}$ (March 1982);

* World Alliance of Reformed Churches: Racism and South Africa (Aug 1982).

After reading the documents carefully, I designed a "grid" of four headings that "emerged" from the material. They will form the outline of this essay where each is discussed in relation to the Belhar text:

\section{A confessional interpretation of the situation in South Africa}

2. The biblical and theological sources cited in support of such an interpretation

3. Core theological themes relevant to the SA situation

4. A vision on social change in SA.

7 See Andrew Prior (1982:167-195 for a full list of statements and pastoral letters issued by the bishops between 1952 and 1982. The choice of one such statement is clearly not representative of SA Catholic views in this period, but does provide some insight into its stance around 1957.

8 The dissenting voices from within the DRC are mostly described in terms of powerful individuals like Bennie Keet, Ben Marais and Beyers Naude. There were however more such voices of which Willie Jonker was, theologically speaking, the most influential inside the DRC. (His legacy still needs to be made available to a broader English readership). By the 1980s these individual voices assumed a wider base amongst ordinary dominees within the DRC. Two of the most significant protests were the Hervormingsdaggetuienis (31 Oct 1980) by eight leading academics, and the Open Letter signed by 123 people (formulated by March 1982; first published 9 June 1982 in Die Kerkbode and later discussed in Bosch, König and Nicol 1982). For the sake of our analysis, I refer to the Open Letter which, because of its wider base, could assume at least some legitimacy, although it was never accepted as official church document like the others. Dissent from the Gereformeerde Kerke in this period is evident from the Koinonia declaration in 1977 in which apartheid and its Christian justification was rejected. 


\section{A CONFESSIONAL INTERPRETATION OF THE SITUA- TION IN SOUTH AFRICA}

There are obviously many perspectives on a "situation" like the one emerging in SA after 1948. These may vary amongst disciplines like history, politics, economics, sociology and theology, and amongst different schools of thought within these disciplines. The contrasting theological views in support of and against apartheid have been well documented and discussed. All the statements listed above does in one or another way express a view on the situation as interpreted by the compilers at the time of their statement.

What is interesting to note, is the development from strong theological disapproval to the technical language suited to a confessional interpretation ${ }^{9}$ of the situation.

One would for example not expect to find "confessionalist" language in a Catholic document. However the 1957-statement alludes twice to the spirit of a confessional interpretation: First it declares "the principle of apartheid as something intrinsically evil", and notes the innumerable offences against charity and justice flowing from "this fundamental evil of apartheid" (my emphases). Toward the end of their statement the bishops direct an earnest plea to white South Africans "to consider carefully what apartheid means: its evil and anti-Christian character..." (my emphasis). It clearly is no mere condemnation of apartheid's effects or application only (as was later argued by some in the DRC), but of the principle in toto, using theological language ("evil" and "anti-Christian") that signals strong disapproval and rejection.

Second: "The white man makes himself an agent of God's will and the interpreter of God's providence in assigning the range and determining the bounds of non-white development. One trembles at the blasphemy of thus attributing to God the offences against charity and justice that are apartheid's necessary accompaniment" (my emphasis). This is very strong theological language and unambiguous in its confessional intent. Blasphemy as used here in its ethical sense ("offences against charity and justice"), is no less theological in its depiction of false prophecies ("agents of God's will and interpreters of his providence") with the added dimension of racist supremacy where some "play God"

9 For an excellent treatment of status confessionis, read Smit 1984b. It is interesting to note that the WCC's Central Committee requested members in 1980 "to declare as a fundamental matter of faith that the doctrine and practice of apartheid is a perversion of the Christisan Gospel" and that members should express this through a confession of faith, a covenant, "status confessionis", or equivalent commitment (see Van der Bent 1986:71). 
(my words) over the lives of other, thereby inadvertendly falling into idolatry.

The question about the formation of a confessing church arose after the Sharpeville killings, and when the results of Cottesloe (1961) were rejected by the DRC's regional synods. It was in the first years with heightened security and the Rivonia trial after the banning of the Communist Party and the ANC. The now well-known Rev Beyers Naude had in the meantime set up the Christian Institute. In a number of articles in Pro Veritate, between July and December 1965, he spelled out his view on why the time has arrived for a confessing church (see De Gruchy 1983, De Gruchy and Villa-Vicencio 1983:76-77).

This theme arises in the 1968 Message to the People of South Africa with greater clarity. The very first line sets the tone: "We are under an obligation to confess anew our commitment to the universal faith of Christians, the eternal Gospel of salvation and security in Christ Jesus alone". For the first time we hear an official SA church meeting depict the political policy of racial separation in terms of doctrine, making it an issue of faith. In clear language the statement reads: "We believe that this doctrine of separation is a false faith, a novel gospel..." (my emphasis), and its concluding paragraphs demand a clear choice between a commitment to an ethnic group or to Christ.

In the subsequent years, the debate widened to include contributions from the Netherlands and Germany, notably Eberhard Bethge who, after a visit to SA in 1973, wrote that "(I)n many quarters the view now is that a status confessionis now exists, and some individual Christians sacrifice themselves to draw public attention to this fact"10. This ecumenical awareness informed the Lutheran World Alliance meeting in Dares-Salaam in 1977. Addressed by bishop Manas Buthelezi from SA on the issue of a status confessionis, the ensuing statement is nothing but a clear confessional declaration. It starts: "The Lutheran Churches are confessional Churches". This is motivated with a reference to Scripture and the Augsburg Confession, and the need for "concrete manifestations" of this confession. Well aware of their own past, the Lutherans note that "political and social systems may become so perverted and oppressive that it is consistent with the confession to reject them.." They then appeal to the white member Churches in Southern Africa "to recognise that the situation in Southern Africa constitutes a status confessionis" (my emphasis). The implication is that "churches would publicly and unequivocally reject the existing apartheid system".

10 See De Gruchy (1983:77) and original reference in note 9, page 91. 
In this statement the threshold between adiaphora (neutral matters) and confession has decidedly been crossed. The scene was set for the South African churches ${ }^{11}$ to take this up. And one could hardly ask for a more appropriate church than the Dutch Reformed Mission Church (DRMC) - itself the product of church separation, and its members suffering under apartheid - to take the baton further. Under the charismatic, theologically informed, and strategic leadership of Allan Boesak, the road was paved toward a confessing church. The founding charter of ABRECSA (Alliance of Black Reformed Christians in Southern Africa) in 1981 takes the same line as the Lutheran statement: "We... unequivocally declare apartheid a sin, and that the moral and theological justification of it is a travesty of the Gospel, a betrayal of the reformed tradition, and a heresy" (my emphases). With this statement the theological initiative in the DRC-family shifted toward its black members ${ }^{12}$, and toward one of its daughter churches. Although the technical term status confessionis is not used by ABRECSA, the confessional interpretation of the political situation is clearly upheld.

A year later, Alan Boesak is elected as president of the World Alliance of Reformed Churches in Ottowa. His opening speech is printed as first chapter in Apartheid is a heresy and is a powerful call for the Alliance to take a strong stance against racism as such (it is a sin, and a form of idolatry) and against apartheid in particular: "In South Africa... apartheid is not just a political ideology. Its very existence as a political party has depended and still depends on the theological justification of certain member churches of the WARC. For Reformed Churches, this situation should constitute a status confessionis. This means that Churches should recognize that apartheid is a heresy, contrary to the Gospel and inconsistent with the reformed tradition, and consequently rejected it as such" (De Gruchy and Villa-Vicencio 1983:8). It is now history that such a decision was indeed taken, resulting inter alia in the suspension of the two white Reformed Churches from $\mathrm{SA}^{13}$.

11 The Open Lettter of 1982 does not use technical confessional terms, but clearly states: "The church will always witness that no societal order may proceed from the fundamental irreconcilability of people or groups of people and set up a societal order based on such a principle" (2.1.2, my translation).

12 Allan Boesak's book Black and Reformed remains an important milestone in the development of an indigenous Reformed theology in South Africa.

13 The refusal to share the Lord's table in Ottowa with representatives of the white churches was an ironic twist in the long history of table-exclusion started by the now notorious decision of the Cape DRC in 1857. Feedback from Ottowa was delivered to a packed audience in the Kweekskool at Stellenbosch. When asked by the dean to thank the speakers, Prof Willie Jonker made a short unprepared speech, inter alia 
In September of the same year, the General Synod of the DRMC met (Rev Mentoor as moderator, Dr Boesak as assessor), and formulated A Statement on Apartheid and a Confession of Faith. In it the church clarifies that it already took a stance in 1978, that the Ottowa decision was a consequence of this, and that (after confirming Ottowa) "we can do no other than with the deepest regret accuse the NGK of theological heresy and idolatry"14.

At the synod it was then felt that the clarity of the "no" should be matched by an equal clarity of the "yes" (see Barth 1948:704). A small commission was tasked to draw up a draft confession that was accepted, widely circulated in the Mission Church afterwards, and formally adopted four years later as the Confession of Belhar.

As one would expect, Belhar stands squarely in the tradition of the Confessing Church. Although it does not refer to the status confessionis as technical term in either the accompanying letter or the confession itself, the letter puts itself and the ensuing confession in the ambit of the status confessionis: "We are deeply conscious that moments of such seriousness can arise in the life of the Church that it may feel the need to confess its faith anew in the light of a specific situation". In paragraph two it speaks further of "this objectionable doctrine" and "such a false doctrine". In Belhar itself all three rejection-clauses in sections two to four commence with the words: "Therefore, we reject any doctrine..." (my emphasis, note slight wording difference in section four), thereby clearly confirming the pattern established by antecedent church declarations of viewing the socio-political situation from a confessional perspective.

If we accept that the institutionalisation of the apartheid state after 1948 was not possible without theological legitimisation, nor that the system could be maintained against considerable political and economic odds without religious, moral justification, then we begin to understand the significance of a status confessionis: it destroyed the Christian

saying: "It may be painful, but the voice of Ottowa is the voice of the Holy Spirit from the ecumenical church to the DRC".

14 I had at that stage just completed my seminary studies and was privileged to be present in the synod at Belhar as unofficial visitor. The decision on heresy and idolatry, accepted with a vast majority, was preceded by an emotional appeal by some speakers on behalf of the mother church "who taught us the gospel of Jesus Christ. How can we now call her heretical?" Not seeing the structural, systemic nature of aparheid, the same sentiment was apparent in many dominees of the DRC with a heart for mission and evangelistion. The late Rev Mike Smuts, a well-loved evangelical, remarked to me: "I give up my holidays to preach in the Mission Church over Christmas. Am I now a heretic"? 
foundation of apartheid, and it took less than a decade (but still with tremendous human cost) to formally dismantle the system itself.

\section{THE BIBLICAL AND THEOLOGICAL SOURCES CITED IN SUPPORT OF A CONFESSIONAL INTERPRETATION}

In this paragraph one should note the genre of church declarations. They are normally the outcome of careful deliberation from a consensusseeking community. A certain hermeneutical framework is therefore implicitly taken for granted and one would not normally expect detailed references such as required in a synodical report or theological treatise. How did these statements argue from the Bible and tradition, and is there a link from these arguments to Belhar?

The Catholic bishops of 1957 focused on the two criteria of charity and justice. These are cited twice as a coupled pair with the significant implication that charity (love) without restoration of justice in society, would be meaningless ${ }^{15}$. They derive their content and application from Christ's teaching and "the change of heart and practice that the law of Christ demands" (my emphasis). In this way the bishops' statement takes its legitimacy from Scripture and clear biblically aligned criteria for a social-ethical evaluation of the SA situation at that time.

The Cottesloe statement with its surprisingly detailed and wideranging social comment (see point 4 below), takes a decisive stand in the first section: "In its social witness the Church must take cognizance of all attitudes, forces, policies and laws which affect the life of a people; but the Church must proclaim that the final criterion of all social and political action is the principles of Scripture regarding the realization of all men of life worthy of their God-given vocation" (my emphasis). The Message (1968) is couched in much stronger proclamative terms. After the confessional opening line referred to above, a sevenfold exclamation of "The Gospel of Jesus Christ..." follows like beatitudes, making absolutely clear wherein the authority and content of the message lie. The very title of the statement as a "message" already foretells what would follow: The Gospel, the will of God for South Africa today.

Part of ABRECSA's significance lies in the fact that it provided a platform and stimulus for black people of Reformed conviction to challenge the white face of Reformed theology (both English and Afrikaans) with its exclusive origin from and orientation toward Europe.

15 See the devastating analysis and critique offered by Johann Kinghorn (1986:169174) on the ethics of "gun aan ander" that was frequently used to support separate development. For an interesting view on the relation between reconciliation, justice and peace from a covenantal theological perpective, read Adrio König (1989). 
But (more importantly) it aimed at reclaiming the inner thrust of the Reformed tradition - inextricably linked to apartheid in SA - for the cause of justice. "What does it mean to be black and Reformed in Southern Africa today?", was indeed the crucial question (see charter motivation 2.4).

In the light of this Reformed confessional orientation, one would expect as first statement of the theological basis: "The Word of God is the supreme authority and guiding principle revealing all we need to know about God's will for the whole existence of human beings. It is this Word that gives life and offers liberation that is total and complete". Herein lies the classical Reformed belief about the claritas and perspecuitas of the Scriptures linked to its liberative intentions. The actual ABRECSA-statement set up a rhetorically powerful antithesis between a false and true interpretation of the Reformed tradition ${ }^{16}$ : In direct contrast to the just quoted basis on the Word of God, ABRECSA rejects an interpretation of the Reformed tradition where "(T)he Word of God (is) subjected and made subservient to the claims of cultural and racist ideology" (4.1).

Apart from the insistence on the Word, there is an almost defiant and proud reclamation of the tradition to ensure "a truer understanding" thereof (point 6). This is accomplished by "declaring unequivocally that apartheid is a $\sin . .$. and a betrayal of the Reformed tradition" (point 7) followed by a specific reference to the Belgic Confession (point 8) with a terse conclusion: "This is our tradition. This we will fight for" (point $9)$.

This Word-tradition-argument is typical of Reformed theology ${ }^{17}$ where Scripture is the ultimate authority, and tradition always under Scripture, but held authoritatively because of confessions' correspondence with Scripture (the quia view). This was carried forth into the Ottowa meeting of WARC the next year, and even the wording indicates that Ottowa took its cue from ABRECSA: After declaring that the situa-

16 One can see this from the corresponding but antithetical sections in points 4 and 5 which is already a precursor to a confessional style where statements of faith are followed by statements of rejection.

17 The Open Letter reflects the same spirit: it contains a number of direct and indirect Scriptural references, and based its prophetic witness on the assumption that a Christian state would listen with the church to the Word of God (2.2.1). As confessional bases, the Apostolicum and Nicea (1.1.5) are mentioned as testifying to the normative unity of the church, whereas art 27 of the Belgic Confession is used to argue that no other critierion than faith may be used for membership of the church (1.2.2). Churches in the DRC family with the same confesssional basis need therefore to express their unity in visible form (1.2.3). 
tion constitutes a status confessionis, the meeting states: "We declare with black Reformed christians of South Africa that apartheid is a sin, and that the moral and theological justification of it is a travesty of the Gospel and, in its persistent disobedience to the Word of God, a theological heresy" (see ABRECSA declaration point 7). This was again confirmed at the DRMC synod later that year in the very same format: a declaration of status confessionis, then a judgement of apartheid as a sin, and defence thereof a theological heresy. But at this point the principled stance, the specific view of the situation - slowly and carefully emerging from the local and ecumenical churches' witness over two decades gave rise to the actual act of confessing itself: Belhar was borne.

There is a marked difference between Belhar and the preceding documents with regard to its claim to be nothing more than a Scriptural confession in line with the ancient- and Reformed confessional tradition. Even a cursory look at Belhar shows the difference: each of the three middle articles (2-4) is provided with lists of supporting texts and pericopes. It is clearly not the aim to represent an exegesis of each text Belhar wishes to demonstrate though that it carries forth the main themes of unity, reconciliation and justice as found in Scripture whence it claims its authority ${ }^{18}$. The present article is looking into Belhar's recalling of the church's confessional tradition, so the very first two sentences strike one as directly related to the Heidelberg Cathecism (Belhar art 1, Heidelberg question/answer 54) and the Apostolicum (Belhar art 2, Apostolicum art 9). There are indeed more of these examples, but the point is evident.

It might have to do with its distinctive character as a confession, but Belhar is very attentive to the fact that it does indeed demonstrate its correspondence to Scripture and the church's confessional tradition beyond any doubt.

\section{CORE THEOLOGICAL THEMES RELEVANT TO THE SA SITUATION}

A contextual interpretation of the Gospel usually has a "closure effect" where the multi-dimensional and poly-interpretable meanings of the Word are restricted to one or two focussed interpretations. This is true of the canon itself, and is part of the church's continued interpretation of the Gospel for its own time. This is particularly evident from great events like the Reformation, the rise of various liberation theologies

18 Apart from the elaborate and detailed defense of the much debated Belhar, article 4, by Dirkie Smit in A moment of truth (Smit 1984a), one finds some exegetical work on Belhar's use of Scripture in Van Niekerk (1996, especially his point 4), Daniels (2001 on Belhar art 2) and Meyer (2000 on Belhar and Luke). 
(political, feminist, womanist, black, and ecological) and the insight that all theologies are in fact "local", despite the power and dominance of Western theology with its purported "universalist" character ${ }^{19}$. This is even more the case regarding confessions with their implicit "kairoscharacter" and clear choice of a specific Word from God for now (see Naude 2003).

The question now arises: what were the dominant theological themes, if any, put forward by the church in the years leading up to Belhar? And what impact, if any, did they have on Belhar's final formulation? From my analysis three clear focal points emerged: (3.1) the visible unity of church, (3.2) the Lordship of Christ, and (3.3) a common humanity.

\subsection{Ecclesiology: The visible unity of the church}

It is interesting to read the documents and find that the foremost theological issue relates to the church. In the context of church formation along racial lines, motivated from a particular view on mission and a specific neo-Calvinist-inspired interpretation of Scripture (see Kinghorn 1986:100ff), one would expect strong affirmations of the unity of the church. There was a deep sense that what is at stake is in the first place not a new political ethic or theory of social change. In line with the confessional view of the situation, and in the context of a de facto corpus Christianum $^{20}$, there was no doubt that if the church could find a true unity in herself, changes in society would be inevitable (see Naude 2001:88-90). This assumption - clearly underlying all the statements - is a necessary condition for the bold witness to the unity of the church. In fact, it places this witness in a specific frame: the unity is itself the best the church can offer a society in need of hope that black and white people can indeed reconcile.

The clear statement from the Cottesloe consultation encapsulates this "order" and is a summary of what would return as a theme in the ensuing years: unity that supersedes diversity; no exclusion from the body on racial grounds, and spiritual unity expressed in visible forms. Let us have a look at part II, points 3-6, in more detail ${ }^{21}$ :

19 Robert Schreiter: Constructing local theologies (1985), although somewhat dated, remains one of the best expositions of a "sociology" of theology.

20 Note Etienne de Villiers' (2001) exposition of the theocratic ideal underlying the Reformed tradition generally and the support for the apartheid state specifically. It will be shown below that both supporters and adversaries of apartheid assumed a close church-state-society interaction no longer possible in SA today.

21 I retain the sexist language for historical reasons. 
3. The Church has a duty to bear witness to the hope which is in Christianity both to white South Africans in their uncertainty and to non-white South Africans in their frustration.

4. In a period of rapid social change the Church has a special responsibility for fearless witness within society.

Points 5 and 6 then spell out what this witness would be:

5. The Church as the body of Christ is a unity and within this unity the natural diversity among men is not annulled but sanctified.

6. No one who believes in Jesus Christ may be excluded from any Church on grounds of his colour or race. The spiritual unity among all men who are in Christ must find visible expression in acts of common worship and witness, and in fellowship and consultation on matters of common concern.

The same formulation is found in the ABRECSA charter, although more inclusive of sex and language differences. In the motivation provided, it takes up the painful question of history, identity and theological selfexpression by so-called "mission churches": "Being 'mission churches', they have been divided into separate denominations by the 'mother' missionary societies even though they share the same confessional base, and these divisions are not of their own making" (2.2). In the series of rejections found in the declaration, the ecclesiology against which ABRECSA sets itself up is clear: "The heresy that the unity of the Church is a mystical ${ }^{22}$ one, where ethnicity and culture in fact become a mark of the Church" (4.5).

In the Open Letter the visible unity of the church is seen as direct result of God's reconciling work in Christ. Coming from the heart of the DRC, the issue of unity and diversity is dealt with clearly: unity is primary and a matter for confession, diversity is secondary and serves reciprocal enrichment and not disunity in the church. "The church will therefore struggle against factors threatening its unity" (1.1.3).

At the Ottowa meeting, this ecclesiology assumes a greater urgency and is laid down as the dividing line between authentic and inauthentic forms of the church. In preparation for the suspension of the two white Reformed churches, it is recalled that the Nairobi meeting of 1970 already declared: "The Church that by doctrine and/or practice affirms segregation of peoples as a law for its life cannot be regarded as an authentic member of the body of Christ". As apartheid in fact

22 I am not sure whether the use of "mystical" in stead of the usual "spiritual" was deliberate, as the former is theologically related to Reformed-Catholic differences about conceptions of the church. The overall point nevertheless remains clear. 
"contradicts the very nature of the Church and obscures the Gospel from the world" these two churches are suspended and will be "warmly welcomed back once more" on condition that black Christians are no longer excluded from worship and especially holy communion, concrete support is given to sufferers under apartheid, and synod unequivocally rejects apartheid and commits itself to dismantle the system in both Church and politics (see section II, 4:a-c).

The DRMC has already in 1978 referred to the fact that apartheid takes irreconcilability as point of departure. It now in 1982 affirms that this stands in direct contrast to "the main artery of the Christian Gospel", which is also the main artery of the Church's existence. From this follows: "The visible effect of reconciliation between God and man is the existence of the Church as a reconciling community of people, a unified community" (original emphasis).

The Biblical defence of an apartheid ecclesiology was based inter alia on a link between the Babel and Pentecost events interpreted as if God indeed wills and affirms the plurality of distinct nations. It is only the Message (1968) that directly opposes such an exegesis and the only document of those discussed here with an explicit link between the Spirit and the church. It asserts "the truth proclaimed by the first Christians, who discovered that God was creating a new community in which differences of race, language, nation, culture, and tradition no longer had power to separate man from man". Apartheid on the other hand "insists that we find our identity in disassociation and distinction from each other... it reinforces distinctions which the Holy Spirit is calling the people of God to overcome... This policy is therefore, a form of resistance to the Holy Spirit".

How do these sentiments relate to Belhar?

This pre-eminence of ecclesiology, in the forefront of church witnesses over many years, is reflected in the very structure of Belhar. One could even say that Belhar is in fact an ecclesiological confession and nothing more.

The belief in the triune God in article 1 does not stand alone, but is intrinsically linked to this God "who gathers, protects and cares for his Church". Article 2 confesses the visible unity of the church, followed by reconciliation (art 3), and justice (art 4) established through the church. Here we find confirmation of the pattern seen earlier: there is a movement from the church to the world on the assumption that the intraecclesial realities have a direct and profound impact on the social realities outside the church. Article five concludes the confession with a call to the church "to confess and do all these things" in obedience to Jesus Christ. 


\subsection{Christology: The Lordship of Jesus Christ}

One should see the development of this theological theme in relation to two distinct, but related objectives. The Lordship of Christ, probably one of the oldest "confessional" phrases of the early church, is witnessed to in relation to both its ecclesiological and broader historical significance. Christ as Lord is able to reconcile people and bring them together in one body. This is the Christological foundation for the ecclesiological vision described above. The witness to Christ's Lordship with its "bi-focal" vision is also reinforcing the assumption of an intrinsic link between church and society, and creates the opportunity to chart the way not only for the nature of the church, but also for the relation between church and state where the Lordship of Christ is set against earthly rulers. The latter is a very important point, as the apartheid state found part of its authority in its self-proclaimed Christian foundation, whilst at the same time persecuting those who "mix religion and politics" for revolutionary purposes $^{23}$.

The clearest formulations for this second focal point (Christ's Lordship versus state authority) is found in the Message and in the ABRECSA charter.

The Message states: "The Gospel of Jesus Christ declares that Christ is our master, and that to him all authority is given". This implies that the highest loyalty and primary commitment is due to Him alone, and not to either "one group or tradition", nor "the demands of the South African state" that must be clearly distinguished from "the demands of Christian discipleship". The last two paragraphs of the Message reinforces this twofold vision that Christ is master of the Church (on the one hand) and that Christ is Lord of the world on the other (and "South Africa is part of his world"). The final call is to be committed to Christ alone.

The Open Letter's very structure testifies to its stance on the Lordship of Christ over the whole of life, though it is couched in terms of reconciliation: The church can make a contribution to reconciliation by uniting herself (first part), but equally so by her prophetic witness in society (second part of letter): "We therefore reject any notion that the church may only occupy herself with 'spiritual issues' and further retreats from other spheres of society" (see start of point 2, my translation). "Reconciliation is a prophetic witness to the whole of society

23 The emphasis on "law and order" was linked to the protection of the state's security, and - as emerged from the TRC-hearings - used as basis for persecuting other-minded church leaders. See TRC, vol 4, chapter three: $66 \mathrm{ff}$. 
and therefore the church may not remain silent on issues like moral decay, family disintegration, and discrimination" (2.1.1, my translation).

The ABRECSA charter takes the Lordship of Christ in all life "even in those situations where is Lordship is not readily recognised" as one of its theological basic points, rendering an eschatological significance to this Lordship. In light of this Lordship, Christians are responsible for the reformation of the world as integral part of discipleship, and "obedience to earthly authorities is only obedience in God" (original emphasis; see points $b-d)^{24}$. ABRECSA therefore rejects an interpretation of the Reformed tradition that would allege "the demand of paying uncritical allegiance to the State, which is regarded as divinely instituted" (see statement 4.4). The later quotation from the Belgic confession shows the deep belief that "their cause which is now condemned by many judges and magistrates as heretical and impious will then be known to be the cause of the Son of God" (statement 8).

In the Ottowa-statement, faithful allegiance to Jesus Christ is set over against "the claims of an unjust and oppressive government", and Christians who aid and abet the oppressor is denounced. The theological rationale for this is found in the fact that apartheid is based on a fundamental irreconcilability of human beings, "thus rendering ineffective the reconciling and uniting power of our Lord Jesus Christ" (II, 1a).

It is now instructive to note that the Belhar confession follows the same "order" from Christ's reconciling work in the church (art 2) to his reconciling work in the world (art 3), as well as linking the latter with the issue of church-state-relations. One should therefore read "(w)e believe that Christ's work of reconciliation is made manifest in the Church... " (art 2) in close association with "we believe that God has entrusted to his church the message of reconciliation in and through Jesus Christ" (art 3), where the latter is linked to being salt and light and peacemakers in the world.

The inclusion of a witness to the state is couched in strictly theological language: Belhar's judgement is that the "credibility" of the message is seriously affected "in a land which professes to be Christian", but is built on enforced separation. The rejection clause of art 3 is also not aimed at the state as such, but to the doctrine which sanctions forced separation in the name of the gospel. The theme of commitment to Christ alone in the face of state violence (so evident in the Message and

24 The most elaborate statement on church-state relations from a Reformed perspective is found in the A theological rationale and call to prayer for the end to unjust rule, issued in 1985 (beyond the scope of this essay). See Villa-Vicencio (1986:246ff) for text. 
ABRECSA), is clearly spelled out in the short art 5: "We believe that, in obedience to Jesus Christ, its only Head (note Lordship language), the Church is called to confess and to do all these things, even though authorities and human laws might forbid them and punishment and suffering be the consequence" (my emphasis).

In this way Belhar's Christology remains true to the content and structure of preceding church witnesses: the rule of Christ extends over both church and society, and is professed from the former to the latter. Where the church follows Christ in obedience to his rule, and is resisted by the state, the higher commitment to Christ will prevail.

\subsection{Anthropology: The search for a common humanity}

From a theological perspective, the struggle against apartheid, was indeed - as shown so far - a struggle for the nature of the church and the Lordship of Jesus Christ. But it was at grass-roots level a struggle for humanity and the human dignity of each person, irrespective of his/her race. My impression from the documents under discussion is that this theme is not independently developed, but subsumed under the first two theological views: the church is the one body of Christ where only faith is required for membership; Christ is Lord in society and in his kingdom there is no place for forced separation based on race. If one understands that the dehumanisation under apartheid was made possible by a form of Ordnungstheologie rooted in creation, the issue of the human person and her status in creation is indeed a crucial theme to address.

Apartheid theology did not deny the unity of humanity stemming from the one Adam, but used the creaturely differentiation between man and woman, heaven and earth, light and darkness to argue for a Godwilled differentiation, which was confirmed in the Babel events where God clearly chose against uniformity, and for the pluriformity of nations each with its own language and territory ${ }^{25}$.

This is the subtext of the Message to the People of South Africa which is sensitive to this kind of interpretation:

"The most important features of a man are not the details of his racial group, but the nature which he has in common with all men and also the gifts and abilities which are given to him as unique individual by the grace of God; to insist that racial characteristics are more important than these is to reject what is most significant about our own humanity as well as the humanity of others" (my emphasis). And two paragraphs further, the Message

25 For a critical analysis of the exegesis, see J A Loubser (1987), and recently Louis Jonker (2001). For the theology underlying such an exegesis, see Kinghorn (1986). 
makes a telling and crucial remark: "Where different groups of people are hostile to each other, this is due to human sin, not the plan of the Creator"

Herewith the Message contradicts the assumed apartheid anthropology ${ }^{26}$ in three ways: firstly, there is common humanity amongst all people due to their being created by God. Secondly, people are indeed different, but this is due to the gracious gifts by God to individual people. Thirdly, where enmity arises amongst different groups, this should not be seen as the result of the God's providence (and a reason for legally enforced separation), but rather as arising from sin which was overcome by Christ's reconciling work. This amounts to the direct inversion of an apartheid anthropology. This was constructed on a differentiated creation order, which remained normative despite the recreation brought by the work of Christ and exemplified in the church.

The ABRECSA charter's reference to the indivisibility of the body of Christ, and the demand that the barriers of race, culture, ethnicity, language and sex be transcended, is a surprisingly inclusivist phrase, but not explicitly grounded in anthropology but in Christology. Ottowa states that apartheid incurs "the anger and sorrow of God in whose image all human beings are created" without further clarification, thereby drawing on the strong imago dei-tradition in Christian theology and ethics.

I have remarked earlier that Belhar is primarily an ecclesiological document. One would therefore expect to find a strong focus not so much on our common creaturely humanity, but on the recreated humanity as exemplified in the church, where different languages and cultures serve as enrichment and no longer disunity. Article one refers to the triune God's gathering the church; article two focuses on this communion of saints, where unity is manifested as the people of God pursue community with one another and is built up in the new humanity. In article three the possibility of reconciliation "outside" the church is seen as being fostered by the life of the obedient church "which can open new possibilities of life for society and the world". The rejection clauses of article three (against forced separation on racial grounds) and article four (against an ideology which legitimizes injustices) are both advanced on ecclesiological grounds (recreation), and not on the idea of a common humanity based in creation as such or creation in the image of God.

26 See Kinghorn's contribution to Jonker's Festschrift wherein he develops the outline of different anthropological types, i.e. liberal, racist and nationalist (Kinghorn 1989). 
There is no doubt that this "narrower" focus of Belhar dismantles any trace of Ordnungstheologie, and effectively rejects any trace of enforced separateness based on creaturely features. One might though observe two "weaknesses" in Belhar if read today: one is its assumption of a seamless unity between church and society; the other is its lack of recourse to a common humanity outside the community of faith. These must be seen from the context in which the confession arose, and should be taken into account in a South Africa that is presently much more influenced by the forces of modernity than was the case in the early 1980s.

\section{A VISION OF SOCIAL CHANGE}

Apartheid was a pervasive system that permeated every aspect of individual and society. More than 100 laws at the height of apartheid regulated where people could live, whom they could marry, which school to attend, what type of work they were allowed to do, and ultimately also what they should think. This situation was not only justified on biblical and theological grounds - some apartheid measures were actually put in place by the National Party government at the request of white Reformed churches (e.g. Immorality Act). We have seen above that alternative church witnesses interpreted the situation from a radically different perspective, declaring the South African social order a matter of confession. The question now arises: where pro-apartheid theology made clear prescriptive social regulation possible, would alternative witnesses also hold forth a social vision with clear social regulations? In other words: would one find not only two theologies at work, but also two social visions on change in the South African society? And, ultimately, what would Belhar confess in this regard?

The early Wynberg decision does not deal with any specific legislation. At that stage, in the same year that the NP came to power, a number of apartheid measures were not yet implemented, but the philosophy and direction of the government were clear enough. The circuit therefore "objects against proposed apartheid laws", and put forward the democratic principle of consultation with the people affected, and their consent before any policies are implemented.

The Catholic bishops speak from a time when apartheid was firmly instituted, and fiercely defended against what was seen as a revolutionary, communist onslaught. They follow a firm, but very cautious approach to social change.

On the one hand they are of the opinion that "(A)ll social change must be gradual if it is not to be disastrous". Differential legislation is supported, as long as they aim at providing services for the less 
advanced sections of the population. "A gradual change it must be: gradual, for no other kind of change is compatible with the maintenance of order, without which there is no society, no government, no justice, no common good. But a change must come for otherwise our country faces a disastrous future. That change could be initiated immediately... The time is short. The need is urgent. Those penalized by apartheid must be given concrete evidence of the change before it is too late".

On the other hand a word is addressed to those "who suffer under the sting of apartheid". They are embittered and frustrated and take recourse to revolutionary slogans that require immediate and radical change. A word of warning follows: "They do not stop to contemplate... the complete dissolution of society and perhaps their own rapid destruction in the holocaust. This is particularly true of those who find atheistic communism the inspiration of their present striving and their hope for the future".

Despite these very cautious remarks, the bishops - as seen earlier do not hesitate to call apartheid evil and anti-Christian, and they "deeply regret that it is still thought necessary to add to the volume of restrictive and oppressive legislation in order to reduce contact between various groups to an inhuman and unnatural minimum”.

The events at Sharpeville injected an urgency for social change into the Cottesloe consultation. Cottesloe is therefore remarkable for its enormously concrete social comment with unambiguous views on a number of contentious issues in SA at the time, ranging from direct representation in parliament, land ownership, job reservation and mixed marriages, to fair wages, freedom of worship, fair judicial processes and migrant labour (see sections II and III). There is no doubt that Cottesloe not only provided an alternative theological view of the situation, but in fact carried forth a concrete social vision spelling out the detail for a completely different South Africa (realised about 30 years later) in the same way as apartheid theology involved itself in concrete social arrangements ${ }^{27}$.

This concrete, specific references are reflected again in the Open Letter from within the DRC twenty years later. The generic descriptive term used by the Open Letter to judge apartheid is "an ordering of society based on the fundamental irreconcilability of people and groups of people" (2.1.2). It follows through with some concrete examples by referring to "laws that became symbols of alienation", like mixed marriages, race classification and group areas (see 2.2.4). In its

27 This perhaps explains the strong political backlash against Cottesloe, inter alia by dr Verwoerd himself: politicians have a keen sense of their enemies. 
discussion of justice, the concreteness of a social view is retained: migrant labour, under resourcing of black education, bad housing and low wages are all mentioned (2.2.5) and linked to the broader political system as such: "all people who consider South Africa as their fatherland, should be involved in designing a new societal order" (2.2.6). Such society should be built on justice, which reflects not so much "law and order", but "order and peace", where all people are treated equally and are afforded equal opportunities (2.2.7). Coming from the Afrikaner community itself, this concrete social-democratic view must be understood from the lack of a previous broad based voice against apartheid. This was not so much the case in the earlier ecumenical documents of the sixties and seventies.

By 1968 the Message does not refer to specific details of the apartheid system, but states in general that "many features of our social order will have to pass away if the lordship of Christ is to be truly acknowledged and if the peace of Christ is to be revealed as the destroyer of our fear". This shift toward a "totalised" view with less and less concrete detail, is evident from the Lutherans in 1977 who refer to "the situation in South Africa" and a rejection of "the existing apartheid system". The ABRECSA charter starts off with an inclusive definition of what is meant by "black" and then depicts the South African social order in strong socio-economic terms (oppressor and oppressed). In their decalration the situation is sketched in general terms: "political oppression, economic exploitation, unbridled capitalism, social discrimination and the total disregard for human dignity" (see point 2). Ottowa talks about "the apartheid system" and make a few concrete references to "exclusive privileges for whites" and "large-scale deportation causing havoc to family life" (see II:1).

The lack of "specificity" in the later ecumenical documents may be explained from two perspectives. First, as apartheid settled itself as ideological system, it made no sense to protest against it in a piecemeal fashion. ${ }^{28}$ Second, as explained earlier, there was a clear assumption that, if the theological (ecclesiological) battle is won, the social order - kept in tact by a religious worldview - would inevitably collapse.

This is once again reflected in the Belhar confession. The vision of a new social order is mediated through a vision of the new humanity made possible by Christ in the church. The negative judgement of the societal situation is described in terms like "enforced separation of people on a racial basis" (art 3), and "all the powerful and privileged

28 Although one should not underestimate the moral effect on the system as a whole of the unambiguous rejection of the Mixed Marriages Act by DRC-ethicists in the early eighties. 
who selfishly seek their own interests and thus control and harm others", as well as "any ideology which would legitimize forms of injustice" (art 4), but these are seen in direct juxtaposition to the role of the church who witnesses and stands by those who suffer, and hope for a new social order built on justice.

It is however in Belhar where the "generalist" language serves the powerful purpose of both exposing the SA social system and at the same time transcending it. There is no reference in Belhar to apartheid or the DRC or SA specifically ${ }^{29}$ : The theological judgement and rejections clearly aims much wider to "any doctrine" (articles $2,3,4$ ) or "any ideology" (art 4) wherever it may be found. Thus, Belhar shares the tendency of the preceding church witnesses toward a "totalist" evaluation of the situation and does not focus on specific legislation or apartheid practices. But it gains significantly from its clear historico-transcending theological formulations, sharing the core trait of a genuine confession to speak to all times by speaking to its own time ${ }^{30}$.

\section{CONCLUSION}

The theological interpretation of Belhar is an ongoing task and much still needs to be done. This paper attempted to show that Belhar in some significant ways reflected the theological focal points and assumptions of antecedent church witnesses. The core assumption of making statements or confessing überhaupt is that of a direct link between ecclesiology and sociology: changes in the church itself, as well as changes witnessed to and struggled for by the church, will, according to this thinking, inevitably lead to changes in society. That this was indeed true of South Africa up to the early 1990s is clear from our history of transformation which would not occur without the church's varied and sustained witness.

29 The accompanying letter is more direct at this point: "In our judgment, the present church and political situation in our country and particularly in the Dutch Reformed church family calls for such a decision" (to confess the faith anew) (paragraph 1). The letter however explains that the ensuing confession itelf " $\ldots$ is not aimed at specific people or groups of people of a church or churches. We proclaim it against a false doctrine..." (paragraph 3). Based on official correspondence and decisions, I have argued elsewhere (Naude 1997) that the DRC initially saw Belhar as an attack on itself.

30 There are already signs that some (white) people who feel themselves marginalised by measures like affirmative action in the new dispensation look to Belhar as pastoral source of faith and hope - way beyond the historical intentions of Belhar itself. One may feel uneasy about such appropriation, but it underlines the multiperspectival hermeneutics possible in this case. 
But we need to rethink this strategy as we in the church face new challenges - amongst ourselves, and no less in South Africa today. The ongoing appropriation of Belhar - now part of the church's rich confessional tradition - might help us in this regard.

\section{Consulted literature}

Barth, K 1948. Kirchliche Dogmatik 1/2. Zürich, Theologischer Verlag.

Botha, J \& Naude, P 1998. Op pad met Belhar. Goeie nuus vir gister, vandag en more. Pretoria: Van Schaik.

Bosch, D J, König, A en Nicol, W (red) 1982. Perspektief op die Ope Brief. Cape Town: Human and Rousseau.

Cloete, G D and Smit, D J (eds) 1984: A moment of truth. Grand Rapids: Eerdmans.

Daniels, A 2001. Bybelgebruik in die Belharbelydenis se artikel oor "eenheid". Scriptura 77, 193-209.

De Gruchy, J 1983: Towards a confessing church, in: De Gruchy John and VillaVicencio Charles: Apartheid is a heresy. Cape Town: David Philip, 75-93.

-, 1984 Bonhoeffer and South Africa. Theology in dialogue. Grand Rapids: Eerdmans.

De Gruchy John and Villa-Vicencio Charles (eds): Apartheid is a heresy. Cape Town: David Philip.

De Villiers, E 2001. The influence on the DRC on public policy during the late 80's and 90's. Scriptura 76, 51-61.

Jonker, L 2001 Israel en die nasies: 'n Kritiese nadenke oor die dokument Ras, Volk en Nasie. Scriptura 2, 165-184.

Kinghorn, J (red) 1986. Die Ned Geref Kerk en apartheid. Johannesburg: Macmillan.

Kinghorn, J 1989. Teologie en sosiaal-antropologie, in: PF Theron and J Kinghorn: Koninkryk, kerk en kosmos. Pro-Christo: Bloemfontein, 112-129.

König, A 1989. Is versoening (te) goedkoop?, in: P F Theron and J Kinghorn: Koninkryk, kerk en kosmos. Bloemfontein: Pro-Christo, 130-143.

Loubser, J A 1987. The apartheid bible. Cape Town: Tafelberg.

Meyer, E E 2000. Interpreting Luke with the confession of Belhar. Scriptura 72, 113120.

Naude, P 1997 Die Belharstryd in ekumeniese perspektief. Ned Geref Teologiese Tydskrif 38 (3), 226-243.

-, 2001. The DRC's role in the context of transition in South Africa: Main streams of academic research. Scriptura 76, 87-106.

-, 2003 Reformed confessions as hermeneutical problem. A case study of the Belhar confession, in: Welker, M and Willis, D (eds): Reformed identity and ecumenicity. Grand Rapids: Eerdmans (forthcoming).

Plasger, G 2000. Die relative Autorität des Bekenntnisses bei Karl Barth. Neukirchener Verlag: Neukirchen-Vluyn.

Prior, A (eds) 1982. Catholics in apartheid society. Cape Town: David Philip. 
Smit D J 1984a "In a special way the God of the destitute, the poor, and the wronged", in: Cloete and Smit (eds), 53-65.

-, 1984b.What does status confessionis mean?, in Cloete and Smit (eds), 7-32.

-, 1998. Das Bekenntnis von Belhar: Entstehung, Rezeption, Relevanz, in: J Niemöller: Das Bekenntnis von Belhar und seine Bedeutung für die reformierten Kirchen in Deutschland. Reformierte Kirche: Detmold, 17-33.

-, 2000 Versoening - en Belhar? Gereformeerd Theologisch Tijdschrift 4, 159-173.

Van der Bent, Ans (ed) 1986. Breaking down the walls. WCC statements and actions on racism 1948 - 1985. Geneva: WCC.

Van Niekerk, A C J 1996. Moet ons die belydenis van Belhar (1986) as 'n nuwe belydenisskrif aanvaar? Skrif en Kerk 12(2), 443-455.

Villa-Vicencio, Charles 1986 Between Christ and Caesar. Classic and contemporary texts on church and state. Cape Town: David Philip. 